\title{
(2)

\section{A Transdisciplinary Approach to Unemployment In the United States' Petroleum Industry}

\author{
Christopher Kreger, Daniel Moran, Stacie Therson, Raytheon Corporation and Texas Tech University, \\ Lubbock Texas, 79409, Email: Jerome.Moore@TTU.edu and Adam.Hines@TTU.edu
}

Received 29 June 2017; Revised 18 July 2017; Accepted 20 July 2017

Copyright (C)2017 Christopher Kreger, Daniel Moran, and Stacie Therson. This is an open access article distributed under the Creative Commons Attribution License (https://creativecommons.org/licenses/by/4.0/), which permits unrestricted use, distribution, and reproduction in any medium, provided the original work is properly cited.

Available online 22 July, 2017 at www.atlas-journal.org, doi: 10.22545/2017/00089

U nemployment in the petroleum industry is a complex issue with social implications, such as unemployment, poverty, and economic deprivation. With the industry supporting 9 million jobs within the United States alone, it can have far reaching impacts for the whole economy. Approaching this issue from a Transdisciplinary perspective, allows for an inherently holistic view of both the problem and solution spaces.

Keywords: Petroleum Industry, Transdisciplinary, Unemployment.

\section{Introduction}

The petroleum industry, often referred to as the oil and gas industry, is present in all fifty states and accounts for a large share the United States (U.S.) work force and gross domestic product (GDP). When discussing the petroleum industry, this includes exploration, extraction, refining, transport, and marketing for petroleum products. According the American Petroleum Institute, in 2011, the petroleum industry employed 5.6 percent of the United States workforce, and accounted for 8 percent of the national GDP [1]. With such strong ties to the United States economy, a large change in the employment rate for petroleum industry has the ability to impact the overall United States unemployment rate. If the petroleum industry was stable, this might not be of much concern, but history has shown it to be a cyclic industry.

Looking at the extraction area of the petroleum industry alone, it is easy to see the impact of these cyclic swings. At its height in 1981, oil and gas extraction accounted for 4.3 percent of the United States GDP, but by 1999 had declined to a mere 0.6 percent [2]. In 2011, when new advances led to the shale boom, it rose to 1.6 percent of the GDP, but dropped to only 172,400 individuals ( 0.1 percent of the work force) by the end of 2016 [3].

While the petroleum industry has historically experienced cyclic boom and bust swings, overall it has been slowly declining. This all results in increased unemployment within the United States. An economy with a high unemployment rate is typ- 
ically in a recession, and is not considered healthy. A 2014 Gallup poll found unemployment was the number one concern amongst the U.S population [4]. Unemployment is a problem that can have far reaching effects for any society including poverty and economic deprivation. Studies have found that unemployment can have effects at the individual and community levels. An individual may suffer from not only poverty, but also mental and physical health issues, including depression and increased mortality, and even detrimental changes to family relationships [5]. Given the known negative effects of unemployment for both the individual and the economy as a whole, unemployment is a metric many governments track and try to influence.

\section{Transdisciplinary Approach}

There exist several tools in the current workspace of large scale or complex problem solving, specifically designed to enhance the value of, and reduce the time synthesizing, the potential solution set for resolving complex and large scale problems. The strategies which see the most widespread use in this space today include the multidisciplinary approach, the interdisciplinary approach, and the transdisciplinary approach. More commonly used in engineering environments today is that of the multidisciplinary approach. In this approach, experts within singular domains come together in a working group, with the goal to come up with an approach to understanding, handling, or solving a complex issue. The key to keeping this multidisciplinary lies in the way that the experts, with the domain knowledge of the respective fields involved, confront the issues. In a multidisciplinary environment, team members utilize their skillsets autonomously as a means to come up with domain specific solutions. Once results for each respective expert have been found, the synthesis of the solution space occurs when all experts come together with their individual ideas to share, and find out if there are contradictory findings. While this method has been adapted for use, with the intent to greatly accelerate learning in developing areas, where traditional methods for educational divestiture of knowledge still use frame works devised in previous era's solely due to the previously isolated nature of such locations [6], the process involved for multidisciplinary discussion becomes increasingly bogged down through multiple iterations during the synthesis phase. When domain knowledge experts come together with their isolated solutions, the discovery of contradictory evidence leads to iterative isolated recursions through the multidisciplinary process, meeting and evaluating until a solution is finally arrived at. While this specific methodology works in a modern day, highly evaluative environment [7], the impact on synthesis when bound by time becomes an increasingly glaring problem that has to be accounted for.

The second commonly used strategy, interdisciplinary evaluation, seeks to bypass the issue of iterative group comparison from single knowledge experts meeting to find contradictory results by implementing collaborative approaches for the synthesis of problem areas. Interdisciplinary approaches within academia have seen rapid success in tunneling through the artificial constraints that a standard multidisciplinary approach has inherent within its own structure [8]. While both multidisciplinary and interdisciplinary approaches have applicability within their academic fields of study, the application of these processes to real world issues, with temporal, fiscal, and political restraints are less than optimal.

The transdisciplinary approach presents as a method to integrate both classically trained, education based subject matter experts along with externally knowledgeable experts. This approach allows for the mapping of the transdisciplinary framework onto problems with effects found in both civil and academic areas, with specificity in the domain, where those areas transcend their boundaries and intermingle. When transdisciplinary tools are utilized in this manner, the benefits of having both academically collaborative research, as well as industry specific expertise allow the synthesis of the potential solution set to occur more rapidly, with more robust solutions [9]. Based on this, the transdisciplinary approach is the selected approach for evaluating the factors involved in unemployment within the U.S Petroleum industry.

\section{Influential Factors}

There are a number of factors which can impact unemployment in the petroleum industry. The basis of evaluation for which, will review the key elements of the process involved in performing Transdisciplinary research. Namely, that there are three primary phases: Phase 1 - Team Building and Collective 


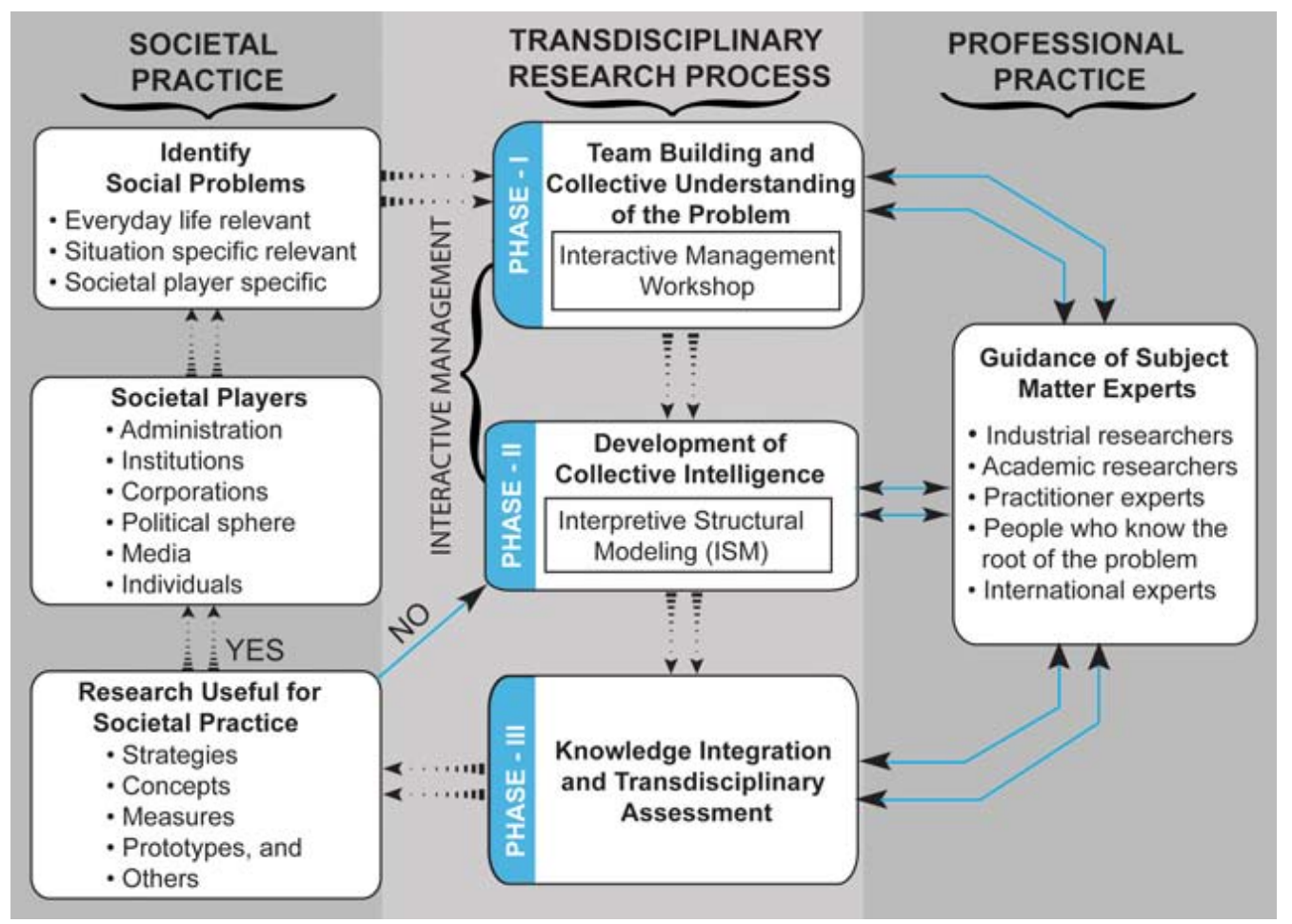

Figure 1: Transdisciplinary research process flow [10].

Understanding of the Problem, Phase 2 - Development of Transdisciplinary (TD) Collective Intelligence and Phase 3 - Knowledge Integration and Transdisciplinary Assessment (See Figure 1). In Section 3, we focus on Phase 1 of the transdisciplinary Research Process while detailing the interactions within the "Professional Practice" domain through the use of the Kano style survey. In this phase of the research, our team touches on the concepts of Interactive Management, Collective Intelligence and the use of TD Generic Tools (e.g., Nominal Group Technique (NGT)). The use of each of these three aspects of the Transdisciplinary Methodology useful for Societal Problem Solving (SPS) offers the best opportunity for positive results from the research efforts.

An Interactive Management Workshop was conducted in order to engage in team building activities and come to a collective understanding of the problem. The Interactive Management Workshop included members of the research team, education professionals, working professionals, and researchers in related fields. This group conducted brainstorming activities and documented the possible factors for unemployment in the petroleum industry in the U.S., as a first step to model the relationships of these factors.
As the research team had decided to utilize Interpretive Structural Modeling (See Section 4 below) for further evaluation of the factors, it followed that the Nominal Group Technique (NGT) would be an appropriate method to generate ideas for defining a set of factors for the research. The five basic steps of the NGT process are given as:

1. Clarification of a trigger question,

2. Silent generation of ideas in writing by each group members,

3. roundrobin recording of the ideas,

4. Ongoing discussion of each idea for clarification and editing, and,

5. Voting to obtain a preliminary ranking of the ideas in terms of significance [10].

As the original list of potential factors was developed, it included the following loosely defined and ill organized set of ideas regarding the potential factors for unemployment in the Petroleum Industry: availability of new fields for exploration, the emergence of new technology (e.g., fracking), issues with lease/land Management agreements between companies and land owners, the market share \& competing technologies, the effect of green energy, the 
impact of the coal industry, job market consistency for individuals, profit margins for oil \& gas companies, the price of oil, international supply/demand of petroleum, Organization of the Petroleum Exporting Countries (OPEC) output rates, international demand, exploration and production costs, automation technology, research and development (R\&D) activity levels, front end engineering design (FEED) activity levels, policy \& regulations over the petroleum industry, export tariffs, domestic social issues, environmental concerns, individual employee adaptability (such as personal willingness to relocate/move family), and education levels/skill levels.

Although the initial efforts of the Transdisciplinary (TD) team brought about good discussion, the team needed guidance from subject matter experts in the petroleum industry. As part of a complete TD Team, the Issue experts were need to augment the individuals which already covered the structural modelers and stakeholders. The TD team reached out to an expert in the Petroleum Industry that could help guide the TD Team in reducing the initial list and preparing for a larger engagement with additional subject matter experts in the petroleum industry.

As a result of the involvement of a 38-year veteran and former Vice President within the Petroleum Industry, a reduced and more concise list of potential factors was created. The list included Cost of Labor and Benefits (Taxes, Insurance, Pension, etc.), Social Issues (e.g., Climate Change Activism), Individual Employee's Education/Tradecraft Skill Level, Regional Job Market Competition in the Energy Sector (Wind, Solar, Coal, etc.), U.S. Regulations (EPA, OSHA, FERC, etc.), Lease Operating Expenses, Price of Oil, International Tariffs on U.S. Oil \& Gas Exports, Increase in the Use of Automation Technology, OPEC production and output amounts, International Political Climate and Stability, Individual Employee's Adaptability (e.g., willingness to relocate), and U.S. Import/Export Tariffs.

This resulting list of factors (above) became the basis for a formal Kano Survey (shown in in Appendix A). This survey was sent to more than fifteen (15) subject matter experts that serve as decision makers in the Petroleum Industry. The Kano Survey was utilized as a mechanism to reach out to Issue Experts and devise a final list of factors potentially linked to unemployment in the Petroleum Industry from which the TD Team could move to Phase II and Phase III of the Transdisciplinary Research Process (see Figure $1[10]$ ). The Kano Survey questionnaire, Kano Survey results and Kano Survey evaluation table performed for this project are found as part of the Appendix in Figures A-1, A-2 and A-3 respectively.

As a result of the inputs received from Issue Experts and the Kano survey, the list of factors was reduced to eight (8) for further research. These top eight factors included Lease Operating Expenses, Cost of Labor and Benefits (Taxes, Insurance, Pension, etc.), Increase in the Use of Automation Technology, Price of Oil, International Tariffs on U.S. Oil \& Gas Exports, U.S. Regulations (EPA, OSHA, FERC, etc.), Individual Employee's Education/Tradecraft Skill Level, and OPEC production and output amounts. Social Issues, although not identified by the experts in the Kano survey as a "must" for being included as part of the research, was maintained as a factor for additional research based on the input from the entire TD team. Furthermore, the OPEC production and output amounts factor is consolidated into the "Price of Oil" factor based on Issue Expert notations and inputs upon review of the Kano survey results.

The following section will discuss these eight factors in more detail so that the interactions between the factors are better understood in an effort to apply Interpretive Structural Modeling (ISM) techniques. Beyond defining each factor, the magnitude of each factor's impact is discussed as well as if and how it impacts the other influential factors.

\subsection{Automation Technology Increases}

Lease operating expenses, or LOE, are highly common within the petroleum industry. Costs such as these are considered upstream costs, which oil and gas companies lump in with capital costs. LOE costs are largely affected by the cost of production and maintenance per location, and in some cases can act as one of the precursor cost evaluation objects that lend weight to decisions on whether to begin operating, or retain, shutter, or outright eliminate existing operations. A study [11] performed by The Energy Industry Administration (EIA), found that LOE had a large impact on the viability of sites for petroleum related production. One specific evaluation used as a litmus for this estimation, is the Eagle Ford Region, an onshore play (land based oil rich area) located in Texas. Typical LOE costs include rig related costs; that is, costs directly affected by rig day rates, mud use, the cost of fuel, the cost of land, all of which 


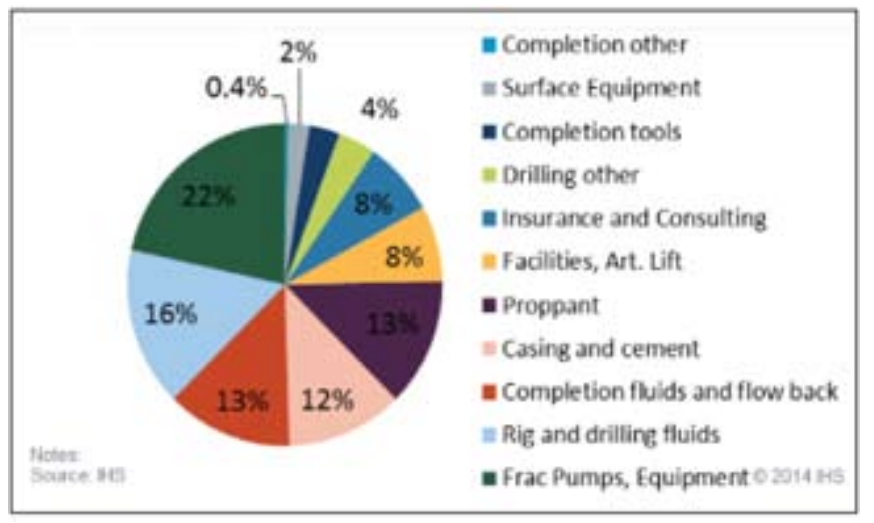

Figure 2: Eagle Ford Capex Breakdown [11].

are directly related to larger market conditions, as well as total drilling activity.

These costs are separate from other factors, such as casing, and drilling and well design and implementation costs. The total combined cost of the Eagle Ford Capex (EFC) Location can be found here, in Figure 2 [11]. From the entirety of these costs, the EFC LOE represents 12-19\% of total capital operating expenses. These expenses, are very inelastic, in comparison to market pricing of petrol products, making the highly rigid LOE costs very sensitive to market fluctuation. One additional factor for consideration, with regard to automation technology increases is the pool of adequately skilled, educated labor. With factors such as globalization, and technological increases, coupled with current corporate trends to shed ancillary business functions down to core competencies, while outsourcing or even eschewing support services, the labor pool for support of automated processes is increasingly growing more homogenized, with a recognizeable gap [12] between the skilled and unskilled labor in the same skein of services, all of which works towards driving the cost, and need, for automation skills, automated labor, and automated solutions.

\subsection{Operating Costs - Lease}

Labor and benefits, as they pertain to the oil and gas industry, are being defined specifically as the cost of operation and maintenance of benefits for individuals employed directly within the industry, including individuals such as roustabouts, field workers, inspection engineers, and component production specialists, as well as support positions, like secondary or tertiary levels of support personnel, such as oil and gas company overhead. Based on an EIA study in 2016 [11], The price of oil, has a direct impact on the ability of oil industry companies to retain skilled labor, even when long term strategies rely on operating at a loss just to retain knowledgeable experts. Additionally, Federal regulations from agencies like Occupational Safety and Health Administration (OSHA) as well as the Environmental Protection Agency (EPA) have a direct impact on the cost viability and base ability of companies, especially during times of loss retention operations. EPA Studies [13], directed at cost options as they pertain to the benefits incurred solely based on U.S. methane production, show that the cost of coming into compliance with existent regulation alone will grow by upwards of $100 \%$ by 2025 , not accounting for new and additionally proposed, as yet unseen regulations. Based on this, the operating cost of labor/benefits are both heavily affected by existing and proposed regulation, as well as the price of oil.

\subsection{Operating Costs - Labor and Benefits}

The growth in recent years of both software based and software controlled automation has been a boon for the oil and gas industry. The ability to remotely or autonomously regulate both equipment and facilities has had a dramatic impact in multiple sectors of the oil and gas industry [14]. Specifically, the replacement of onsite, low skilled labor with automation technology has allowed companies to defray costs typically set aside for liability and health benefits into the hiring of higher skilled labor and autonomous systems. The factors impacting labor are complex, as the replacement of lower skilled labor has been replaced by higher skilled labor with different skillsets and compensation expectations. Additionally, as noted in the labor analysis, the intentional retention of this class of skilled labor can incur costs when companies operate at a loss. Regulation of personnel, as well as the expense involved with lease operating costs, specifically as they pertain to day to day tasks, will both also play a heavy role on the amount of gains seen in the automation portion of the oil and gas sector.

\subsection{International Tariffs on Exports}

A tariff, by definition, is a tax imposed on the import or export of goods and in the case the term 
international tariff refers to the taxes imposed by other countries on petroleum products (oil and gas specifically) that are produced in the United States and exported to other countries for sale. The ability to sell oil and gas overseas goes to the bottom line profitability of Petroleum companies, as it is not always the case that an increase in a tariff rate will be passed along to the consumers of the product in the foreign country. Tariffs, however, work both ways and the United States measures its trade volume in areas of petroleum based on the term "net import" which is the total number of imports - the total number of exports.

"Current tariffs on oil imports range from $5.25 \%$ to $52.5 \%$ per barrel depending on the type of petroleum. 25 oil and petroleum products from certain countries are subject to duty-free treatment under several trade agreements and preferential trade programs enacted by Congress. The North American Free Trade Agreement (NAFTA), the Generalized System of Trade Preferences (GSP), and the African Growth and Opportunities Act (AGOA) account for most of the foregone revenue from waived tariffs. At 2010 import levels, these and other waiver programs accounted for about $\$ 180$ million dollars in foregone revenue, down from $\$ 215$ million in 2005 when import volumes were higher. In the past, an increase in the tariff on oil has been considered a means to provide an advantage to domestic oil producers and reduce imports [from other countries]" [15].

Therefore, when U.S. companies get a trade advantage through tariffs, this results in increased production in specific petroleum products as well as an increase in the ability to expand services and products produced in this industry, thus resulting in impacts to the unemployment rate. Nerurkar [15], goes on to say that "More than $60 \%$ of U.S. exports went to countries in the Western Hemisphere, particularly to countries such as Mexico and Canada from which the U.S. imports crude oil. Exports occur largely as a result of commercial decisions by oil market participants which reflect current oil market conditions as well as past investment in refining". This leads to the conclusion that International Tariffs are not a major driving factor in the unemployment rates of the petroleum industry.

\subsection{Price of Oil}

As stated, earlier, based on an EIA study in 2016 [11], the price of oil, has a direct impact on the

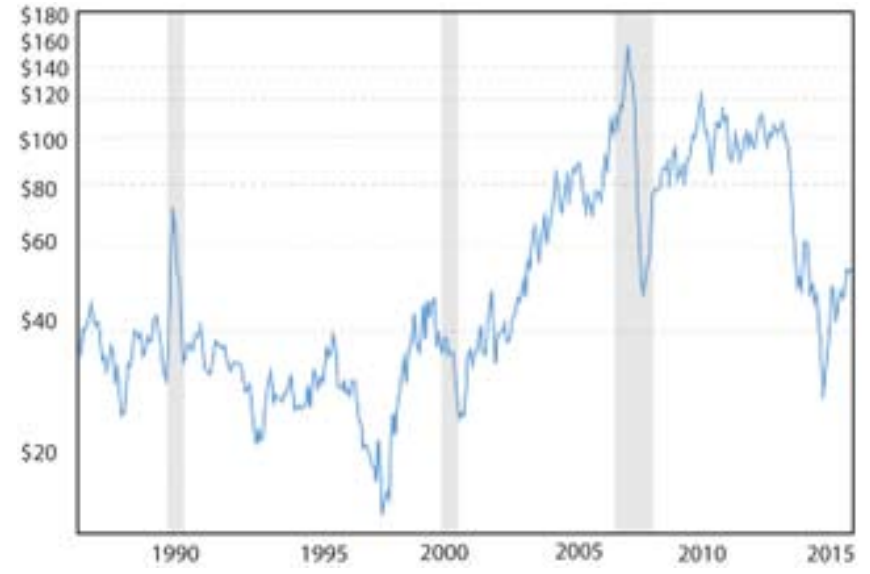

Figure 3: Crude oil price trends - 30 year history [15].

ability of oil industry companies to retain skilled labor and therefore is an impact to unemployment rates. The Price of Oil as seen in Figure 3 has fluctuated between less than $\$ 20$ to as high as $\$ 160$ dollars a barrel over the past thirty years.

According to one of the experts that participated on the TD team, when oil prices are low there is an employment ripple affect all the way up and down the support services and product line within the energy sector. Least affected in the recent history is the downstream refining. Most affected by price in the order of the employment ripple is:

- Drilling

- Drilling Support Services

- Engineering Services

- Field Development/Field Construction Ser-vices

- Production Equipment Providers

- Admin. Personnel

- Mgmt. Personnel

- Field Personnel.

Furthermore, this price of oil directly impacts the profitability of Petroleum Industry companies and is therefore directly linked to the central goal of the business aspects of these companies - namely, to make a profit for their shareholders. Following this logic, and considering the factors that impact profitability, all Operating Costs, whether Lease costs or Labor and Benefits costs that impact profit margins must eventually be passed along through the price 


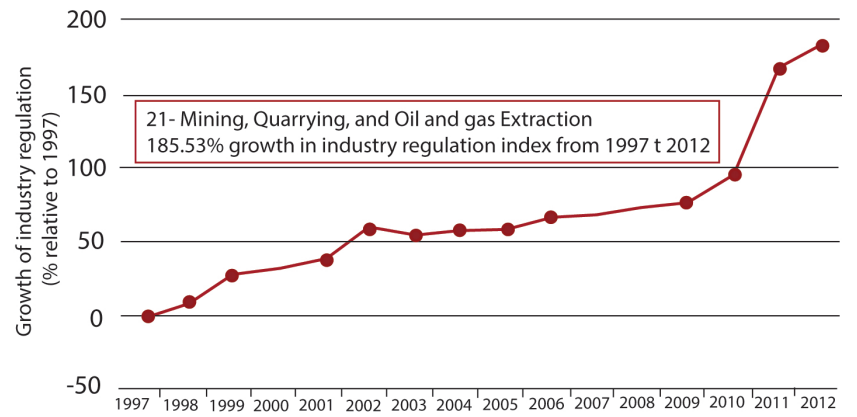

Figure 4: Historical regulation increase within mining, quarrying and oil and gas industry [16].

of oil in order to remain profitable. Additionally, International Tariffs and Regulations, both come with cost that is passed along to the company to respond to and be able to account for the overhead of paying for experts in these areas and sort through the legal paperwork and processes required to continue gaining permits and conducting operations. This cost impacts profitability and therefore the Price of Oil. It cannot be understated, however, the numerous complicating factors which impact the Price of Oil, thereby impact profitability and subsequently flow down to the unemployment rates within the Petroleum Industry.

\subsection{Regulations}

According to data collected by the Mercatus Center [16], three of the top ten regulatory bodies in the U.S., which have significantly increased their number of regulations in the last 15 years, directly influence and oversee aspects of the Petroleum Industry: Environmental Protection Agency (EPA), Operational Safety and Health Administration (OSHA) and Federal Energy Regulatory Commission (FERC). In fact, according to their data, of all the industries that have seen increases in regulations over the past fifteen years, the Mining, Quarrying and Oil \& Gas Extraction regulations have increased $185.54 \%$ between 1997 and 2012 (see Figure 4).

New regulations, bring with them the opportunity for new employment opportunities at the higher end of the professional scale, such as lawyers and finance personnel. A higher degree of education or longer experience within the industry is required to fill these employment vacancies. This increased regulation can also delay new project development (at the front end engineering design phase and subsequent exploration and development phases) as the regulatory issues and process are worked through. The average number of days just to obtain a permit to drill on federal land from the Bureau of Land Management (BLM) was 307 [17] - and this is just one of many permits required throughout the process as the end to end process is regulated at each step: Leasing Land, Seismic Assessments, Site Preparation, Drilling, Well Completion, Production and Restoration [18]. Each step is variable in timeframe, being impacted by regulatory paperwork and oversight, leading to difficulty in predicting employment needs, scheduling resources and work-loads in the industry and impacting hiring strategies as projects are delayed or not approved for continuation due to regulatory oversight. New regulations continue to increase and have a downstream impact on the unemployment rates within the Petroleum industry, driven in part by Social Issues such as Climate Change and New Technology development (e.g., Fracking).

\subsection{Employee Education and Trade Skills}

Education and trade skills describe the skill set of an individual. This skill set includes formal education, such as public high school and college as well as vocational schooling and skills acquired through onthe-job experience. Education and trade skills do not necessarily impact whether or not a petroleum job disappears, they do impact how quickly an individual can transition into another career or industry.

Unemployed workers whose skill set misaligns with the demands of industry are more likely to face long term unemployment [19]. Many of the manual laborers in the oil and gas industry, who face decreasing job security, fit into this category. Figure 5 plots the unemployment data [20] by education level.

According to the Bureau of Labor statistics, more than $50 \%$ of the workforce employed in oil and gas extraction, falls into the unskilled labor category. While many employed in the petroleum industry are highly skilled, those skills do not necessarily translate directly to careers in other industries [21]. For these employees, transitioning into a new career can require years of new training.

As discussed in the section on Automation Technology Increases, jobs are being lost due to automation of tasks that where once performed by manual labor. While many jobs are lost due to this (automation alone is expected to cut nearly $40 \%$ of the oil 


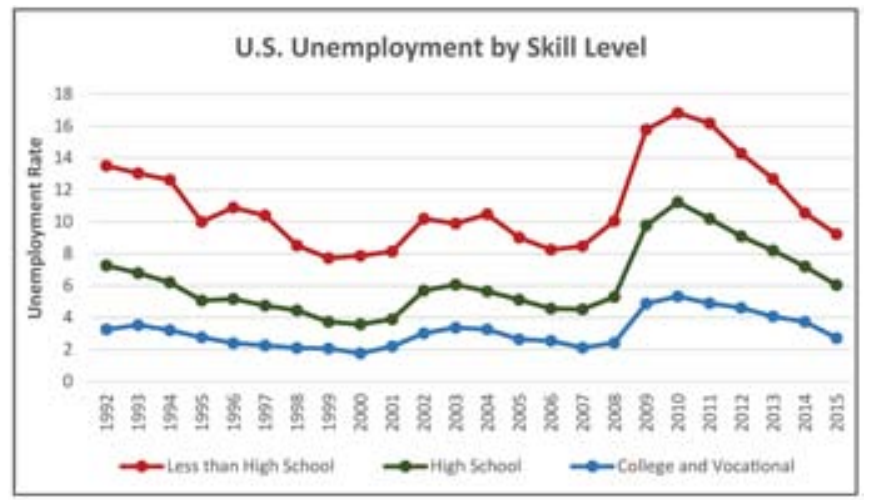

Figure 5: U.S. Unemployment by skill level [20].

drilling jobs in Texas [22]), a smaller number of new jobs are created. These new jobs, which require a different skill set from those that were lost, focus on information technology used to monitor and repair the automated technology. Employee education and trade skills can also impact automation and technology increases. Recent studies have noted a shortage of skilled labor, with some skilled labor jobs going unfilled [12]. After oil prices crashed in 2014, the industry reduced its workforce through lay-offs. Many of the laid off employees have since found jobs with other industries, such as the solar industry, which offers much better stability [23]. With oil prices on the rise and looking to ramp up, the industry is facing a shortage of skilled workers. When faced with a labor shortage, the petroleum industry may turn to automation, as other industries have [24] [25].

\subsection{Social Issues}

A social issue is an idea that influences a significant number of individuals within society, which may have both social and economic facets [26]. The petroleum industry has the potential to be impacted by several social issues:

- Environmental Pressure creating Market Demand for Clean Energy

- Human/Employee Rights, Environmental Protection, Transparency \& Corruption issues. [27]

Considering first the social issue which is driving demand for renewable or clean energy. Studies have found that growth in the renewable energy sector has very little impact on the petroleum industry. This is because the two industries have different markets. Oil is mainly used for transport as vehicle fuel. In contrast, renewable energy sources are mainly used for power production. Oil makes up less than 1

The other social issues (human rights, environmental protection, and anticorruption) can have an impact on the petroleum industry, but mostly through the economic facets. These social issues can lead to laws and regulations, which could then in turn impact operating costs. An example of this can been seen with hydraulic fracturing. Hydraulic fracturing, or fracking, has been a practice used by the petroleum industry since the 1960s, however it has become a focal point of public concern recently. Fracking has risen to the status of a social issue as people became worried about environmental contamination and public health and safety concerns. In response to this social issue, some municipalities have passed laws and regulations banning the practice [30]. As hydraulic fracturing currently accounts for nearly $50 \%$ [31] of the oil produced in the U.S, it is clear, social issue driven regulation and laws do have the ability to impact the petroleum industry.

Social issues also have the ability to influence corporate behavior, stemming from the desire to avoid controversy. Oil drilling specifically can be the center of social controversy due to both environmental impacts and human safety. One response to these social pressures has been to turn to technology and automation. Technological advances have allowed industry to better predict where to drill. These analytical approaches allow for a better success rate when drilling for oil. This has multiple benefits, from reduced operating costs to fewer wells drilled, which leads to a smaller environmental footprint and fewer workers endangered [32].

\section{Application of Interpretive Structural Modeling}

The transdisciplinary approach to large complex problems, provides methods and tools to both understand and solve the issue. Interpretive Structural Modeling (ISM) is a methodology for dealing with complex problems, and it was developed by Dr. John N. Warfield in the early 1970s. ISM leverages graph theory, matrix theory, and mathematical logic, to assemble the influential factors in a meaningful way to develop a collective intelligence and solve complex problems. The following section will apply the 


\begin{tabular}{|c|c|c|c|c|c|c|c|c|c|}
\hline & 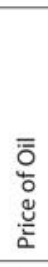 & 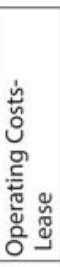 & 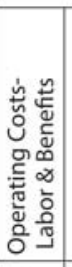 & 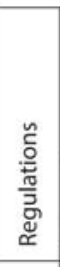 & 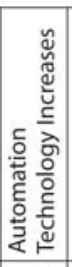 & 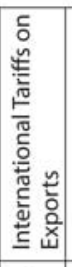 & 先 & 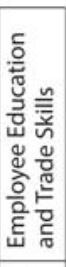 \\
\hline & & 1 & 2 & 3 & 4 & 5 & 6 & 7 & 8 \\
\hline 1 & Price of Oil & & $A$ & $A$ & $A$ & $\mathrm{O}$ & $A$ & $\mathrm{O}$ & $\mathrm{O}$ \\
\hline 2 & $\begin{array}{l}\text { Operating Costs- } \\
\text { Lease }\end{array}$ & & & $\mathrm{O}$ & $A$ & $\mathrm{O}$ & $\mathrm{O}$ & $\mathrm{O}$ & $\mathrm{O}$ \\
\hline 3 & $\begin{array}{l}\text { Operating Costs- } \\
\text { Labor \& Benefits }\end{array}$ & & & & $A$ & $\mathrm{O}$ & $\mathrm{O}$ & $\mathrm{O}$ & $\mathrm{O}$ \\
\hline 4 & Regulations & & & & & $A$ & $\mathrm{O}$ & $A$ & $\mathrm{O}$ \\
\hline 5 & $\begin{array}{l}\text { Automation } \\
\text { Technology Increases }\end{array}$ & & & & & & $\mathrm{O}$ & V & $X$ \\
\hline 6 & $\begin{array}{l}\text { International Tariffs on } \\
\text { Exports }\end{array}$ & & & & & & & $\mathrm{O}$ & $\mathrm{O}$ \\
\hline 7 & Social Issues & & & & & & & & $\mathrm{O}$ \\
\hline 8 & $\begin{array}{l}\text { Employee Education } \\
\text { and Trade Skills }\end{array}$ & & & & & & & & \\
\hline
\end{tabular}

Figure 6: SSIM.

ISM methodology to the issue of unemployment in the U.S. petroleum industry, and will break out the process and results for each step.

\subsection{Modeling with Matrices}

Using the influential factors and Kano Survey, both discussed in detail in Section 3, a Structural SelfInteraction Matrix (SSIM) can be created. The SSIM is an effective way to model the direction of the contextual relationship between the influential factors. Based on the influential factors discussed in Section 3, a SSIM has been created for this complex problem, as shown in Figure 6.

The SSIM is just the first step in modeling the complex problem with matrices. In order to perform mathematical operations on the SSIM, it must be translated into a numerical format. Figure 7 shows this translation of the SSIM into the adjacency matrix.

The ISM process is based on the one-to-one correspondence between the binary matrix and the graphical representation of a directed network. While a directional graph could be generated from this adjacency matrix, it may not correspond to the transitive contextual relation [33]. To accommodate the transitive contextual relationships, another method must be implemented. The reachability matrix and level partitioning are used to translate the adjacency matrix into the final directional graph. "In graph theory, reachability refers to the ability to get from one vertex to another within a graph." [34] The reachability matrix can be obtained by adding the identity matrix to the adjacency matrix, and then raising the resulting matrix to successive powers until no new entries are obtained [35]. Modelling the transitivity with the reachability matrix, results in the final reachability matrix, which is an interconnect matrix, which describes a single system whose reachability is wholly defined for the contextual relationship [33].

Using the adjacency matrix in Figure 7, and applying transitivity results in the final reachability matrix shown in Figure 8. When computing the final reachability matrix with transitivity, driving power and dependence factors are also calculated. These factors will be useful during the cross-impact analysis.

\begin{tabular}{|c|c|c|c|c|c|c|c|c|c|}
\hline & 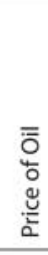 & 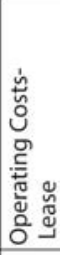 & 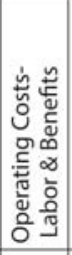 & 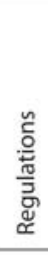 & 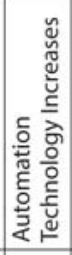 & 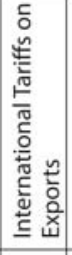 & 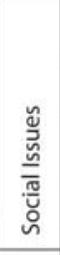 & 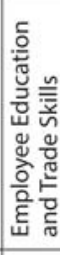 \\
\hline & & 1 & 2 & 3 & 4 & 5 & 6 & 7 & 8 \\
\hline 1 & Price of Oil & 1 & 0 & 0 & 0 & 0 & 0 & 0 & 0 \\
\hline 2 & $\begin{array}{l}\text { Operating Costs- } \\
\text { Lease }\end{array}$ & 1 & 1 & 0 & 0 & 0 & 0 & 0 & 0 \\
\hline 3 & $\begin{array}{l}\text { Operating Costs- } \\
\text { Labor \& Benefits }\end{array}$ & 1 & 0 & 1 & 0 & 0 & 0 & 0 & 0 \\
\hline 4 & Regulations & 1 & 1 & 1 & 1 & 0 & 0 & 0 & 0 \\
\hline 5 & $\begin{array}{l}\text { Automation } \\
\text { Technology Increases }\end{array}$ & 0 & 0 & 0 & 1 & 1 & 0 & 1 & 1 \\
\hline 6 & $\begin{array}{l}\text { International Tariffs on } \\
\text { Exports }\end{array}$ & 1 & 0 & 0 & 0 & 0 & 1 & 0 & 0 \\
\hline 7 & Social Issues & 0 & 0 & 0 & 1 & 0 & 0 & 1 & 0 \\
\hline 8 & $\begin{array}{l}\text { Employee Education } \\
\text { and Trade Skills }\end{array}$ & 0 & 0 & 0 & 0 & 1 & 0 & 0 & 1 \\
\hline
\end{tabular}

Figure 7: Adjacency matrix.

The utility of the reachability matrix is that it can be used to develop a hierarchical restructuring of the directional graph. To complete this, the final reachability matrix, with transitivity must be broken out into hieratically levels, which is accomplished through level partitioning. 


\subsection{Charting the Results}

Level partitioning is used to determine the hierarchical structure of the relationships between the influential factors. From the final reachability matrix, a reachability set and an antecedent set are derived for each factor, where the reachability set consists of the factor and the factors it impacts and the antecedent set consists of the factor and the factors that impact it. The intersection set for each factor, is defined as the set of factors that are present in both the reachability set and the antecedent set. From the structured description, partitioning is done in a cyclical way to order the indexing of the matrix. Following Warfield's partitioning method, the previously developed reachability matrix, Figure 8, has to be structurally partitioned, and can be described as shown in Table 1.

With the level partitioning complete, the binary relational matrix can be converted into graphical form using the theory of directed graphs, or digraphs. Mapping the structural partitioning into a digraph is trivial, and the result is show in Figure 9. The digraph is a visual representation of the influential factors and their interdependence, with the hierarchical level increasing from top to bottom.

\subsection{Cross-Impact Analysis}

Cross-Impact Analysis (CIA) is a methodology for determining how relationships between factors, impact the resulting events. Completion the crossimpact analysis used the dependence and driving power factors, which were calculated for each of the influential factors in the final reachability matrix, previously discussed and shown in Figure 8. The cross-impact analysis was performed using the Impact Matrix Cross-Reference Multiplication Applied to a Classification, or Matrice d'Impacts CroisesMultiplication Appliqe an Classment (MICMAC), which identifies the influential factors that drive the system in various categories; autonomous factors, dependent factors, linkage factors, and independent factors. The result of the MICMAC analysis for our problem, unemployment in the U.S. petroleum industry, is shown in Figure 10.

\begin{tabular}{|c|c|c|c|c|c|c|c|c|c|c|}
\hline & & 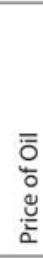 & 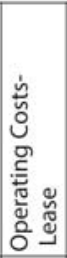 & 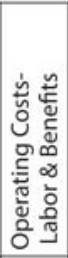 & 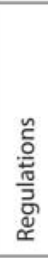 & 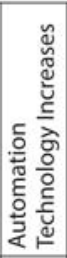 & 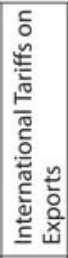 & 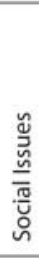 & 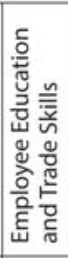 & \\
\hline & & 1 & 2 & 3 & 4 & 5 & 6 & 7 & 8 & \\
\hline 1 & Price of Oil & 1 & 0 & 0 & 0 & 0 & 0 & 0 & 0 & 1 \\
\hline 2 & $\begin{array}{l}\text { Operating Costs- } \\
\text { Lease }\end{array}$ & 1 & 1 & 0 & 0 & 0 & 0 & 0 & 0 & 2 \\
\hline 3 & $\begin{array}{l}\text { Operating Costs- } \\
\text { Labor \& Benefits }\end{array}$ & 1 & 0 & 1 & 0 & 0 & 0 & 0 & 0 & 2 \\
\hline 4 & Regulations & 1 & 1 & 1 & 1 & 0 & 0 & 0 & 0 & 4 \\
\hline 5 & $\begin{array}{l}\text { Automation } \\
\text { Technology Increases }\end{array}$ & & & & 1 & 1 & 0 & 1 & 1 & 7 \\
\hline 6 & $\begin{array}{l}\text { International Tariffs on } \\
\text { Exports }\end{array}$ & 1 & 0 & 0 & 0 & 0 & 1 & 0 & 0 & 2 \\
\hline 7 & Social Issues & & & & 1 & 0 & 0 & 1 & 0 & 5 \\
\hline 8 & $\begin{array}{l}\text { Employee Education } \\
\text { and Trade Skills }\end{array}$ & 0 & 0 & 0 & & 1 & 0 & & 1 & 4 \\
\hline & Dependence & 7 & 4 & 4 & 4 & 2 & 1 & 3 & 2 & $=27$ \\
\hline
\end{tabular}

Figure 8: Reachability matrix with transitivity.

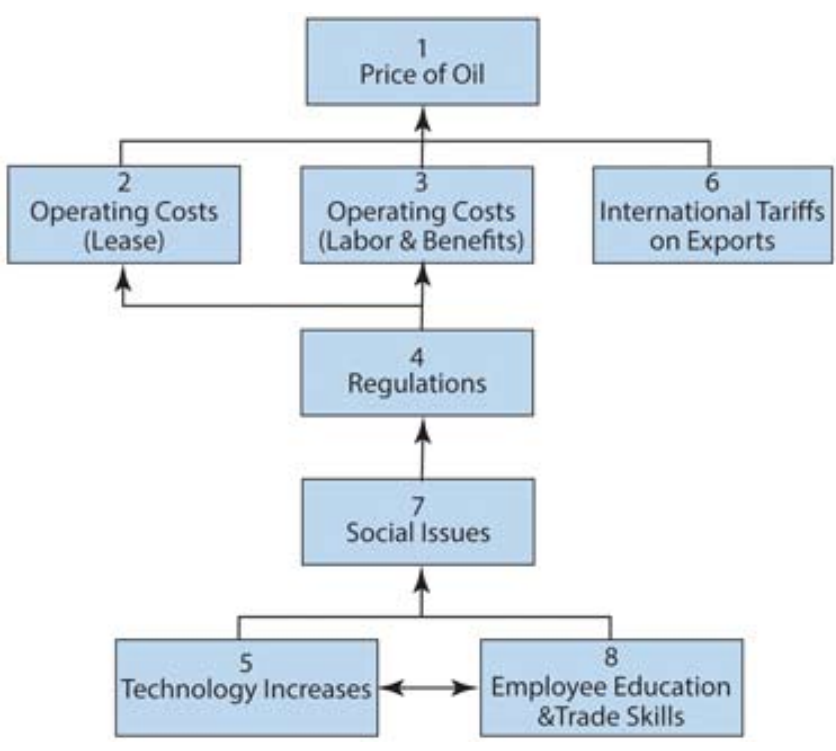

Figure 9: Digraph. 
Table 1: Structural Partitioning

\begin{tabular}{lcccc}
\hline Variable & Reachability Set & Antecedent Set Intersection Set Level \\
\hline 1 Price of Oil & 1 & $1,2,3,4,6,7$ & 1 & 1 \\
\hline 2 Operating Costs-Lease & 1,2 & $2,4,5,7$ & 2 & 2 \\
\hline 3 Operating Costs-Labor \& Benefits & 1,3 & $3,4,5,7$ & 3 & 2 \\
\hline 4 Regulations & $1,2,3,4$ & $4,5,7,8$ & 4 & 3 \\
\hline 5 Automation Technology Increases & $1,2,3,4,5,7,8$ & 5,8 & 5,8 & 5 \\
\hline 6 International Tariffs on Exports & 1,6 & 6 & 6 & 2 \\
\hline 7 Social Issues & $1,2,3,4,7$ & $5,7,8$ & 7 & 4 \\
\hline 8 Employee Education \& Trade Skills & $4,5,7,8$ & 5,8 & 5,8 & 5 \\
\hline
\end{tabular}

When assessing the results of the MICMAC analysis, the factors and their potential impacts are easily identifiable. Linkage factors which are considered unstable as they have a strong dependence and a strong drive are not a concern for this unemployment problem. The dependent factors, which have a weak drive and a strong dependence, may not be the best choice when determining which factors to impact to drive the desired results. For the problem, the only dependent factor is the price of oil. The independent factors are often called the key factors because they impact all of the other factors, and are not impacted by the other factors in return. From this it is clear, that Automation Technology Increases and Social Issues are the two most independent influential factors for this problem. The rest of the influential factors fall into the category of autonomous, meaning they have a weak drive power and a weak dependence.

\section{Design Structure Matrix}

Much like ISM, and other associated tools, the design structure matrix, or DSM, stands as an additional invaluable transdisciplinary tool for use in the deconstruction of complex situations and problems. Designed by Don Steward in the 1960's, the progenitor of the modern day design structure matrix (DSM) approach to the decomposition and evaluation of complex problems was that of using matrices for the production of solution sets comprised of multiple, differently modified matrices, for analysis to help better understand those problems. Based on this strong foundation, DSM, when used as a tool to evaluate complexity, evinces strong utility in the

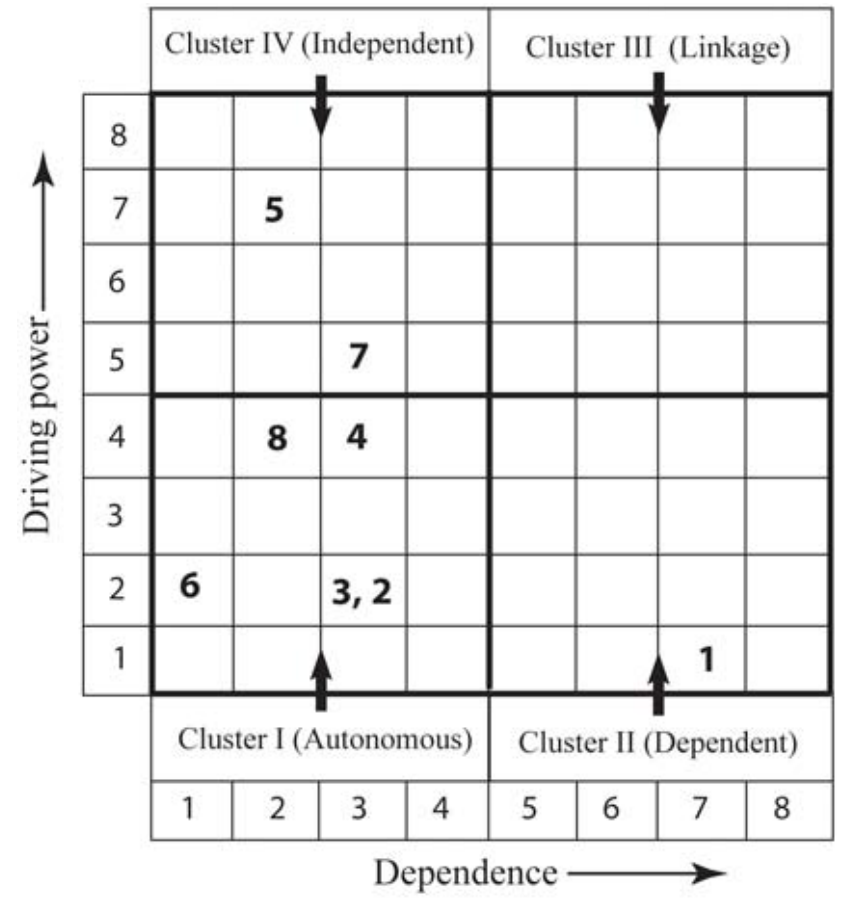

Figure 10: MICMAC Analysis.

analysis of systems, and when used as a tool to understand the connections of multiple dependent factors, becomes a highly useful tool for project planning, as well as for systems and project design.

The choice of using DSM to help deconstruct and evaluate unemployment in the U.S. petroleum industry is based in part on these attributes, along with the applicability and validity of DSM as a tool within the transdisciplinary workspace. Worth noting, too, is DSM's flexibility in clustering and sequencing data, which is of great benefit when DSM is applied towards identifying factors in analysis to assist in the reduction of cost or schedule risk. 


\subsection{DSM - Base Tools and Potential Usage}

Design Structure Matrix (DSM) analysis starts with the adjacency matrix, which was initially utilized for evaluation through ISM. Additionally, the factors chosen for inclusion are those identified in the Kano Survey conducted for the purposes of this paper, designed to identify and correlate the prevalent, impactful factors on unemployment in the U.S. petroleum industry. Techniques which can be used in the analysis of adjacency matrices, typically on larger, more fully interdependent factors, include techniques like the inclusion of multidomain matrices, in which two related sets of matrix data are combined into one. Partitioning is also a strategy typically used which evaluating adjacency matrices. Partitioning allows for more closely related factors within a larger pool of factors to be evaluated together, allowing for a better understanding of potential interdependencies. Additional Techniques available for DSM analysis include tearing, which allows for further analysis of related, looped factors. The objective with tearing, the use for which is outside the scope of the evaluation of the factors identified by the Kano Survey utilized for this paper, is to reorder coupled tasks within the identified blocks of an adjacency matrix, with the purpose of finding an initial ordering to start the iteration process of breaking down, and then reordering the factors involved [30]. Based on the fairly straight-forward nature of the factors found to be involved in the specific topic, the techniques in use with the evaluation of the Kano Survey results are limited to loop combination analysis.

\subsection{DSM - Adjacency Matrix: Creation and Population, and Manipulation}

The initial adjacency matrix, identified in Figure 11, was created by populating the matrix with the final factors identified in the associated Kano Survey as being most impactful. The tool used to create the diagrams included in this paper can be found at theatlas.org (which was free and publically available at the time of this paper's writing).

Next, the matrix was populated with dependent factors. Going by rows, each factor which acts upon another received an indicator of that action in the appropriate row / column location. The resultant adjacency matrix, identified in Figure 12, was the same

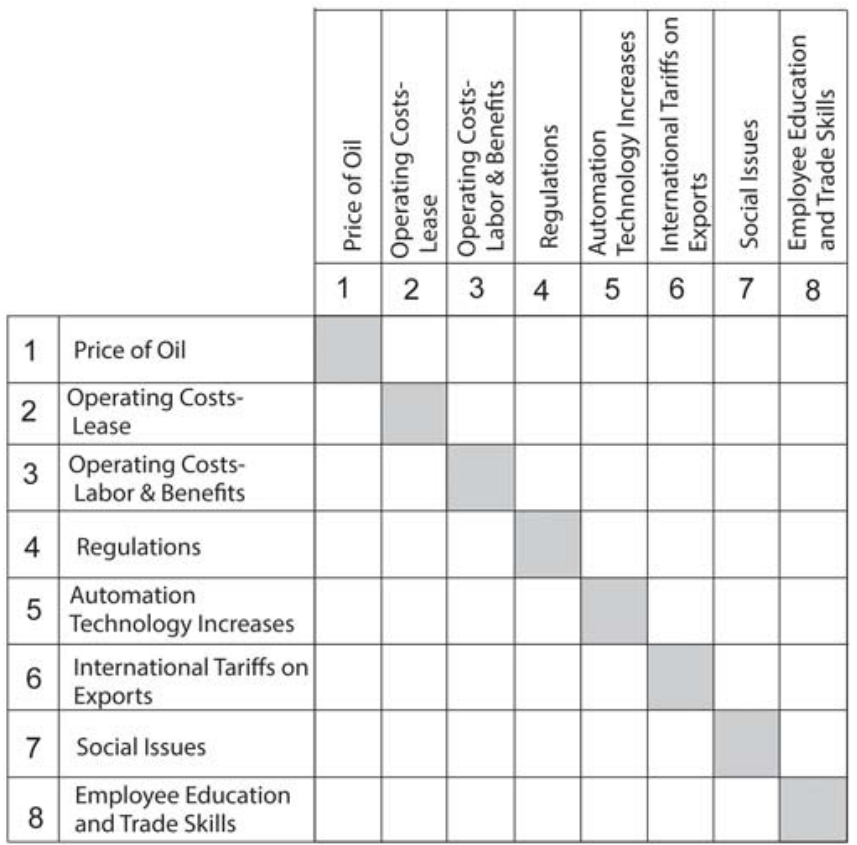

Figure 11: Adjacency matrix, initial.

\begin{tabular}{|c|c|c|c|c|c|c|c|c|c|}
\hline & 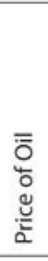 & 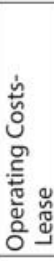 & 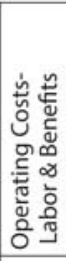 & 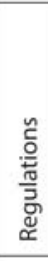 & 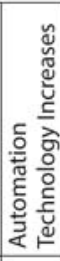 & 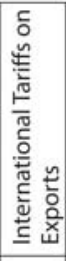 & $\frac{\tilde{\omega}}{\tilde{\omega}}$ & 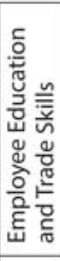 \\
\hline & & 1 & 2 & 3 & 4 & 5 & 6 & 7 & 8 \\
\hline 1 & Price of Oil & & & & & & & & \\
\hline 2 & $\begin{array}{l}\text { Operating Costs- } \\
\text { Lease }\end{array}$ & & & & & & & & \\
\hline 3 & $\begin{array}{l}\text { Operating Costs- } \\
\text { Labor \& Benefits }\end{array}$ & & & & & & & & \\
\hline 4 & Regulations & & & & & & & & \\
\hline 5 & $\begin{array}{l}\text { Automation } \\
\text { Technology Increases }\end{array}$ & & & & & & & & \\
\hline 6 & $\begin{array}{l}\text { International Tariffs on } \\
\text { Exports }\end{array}$ & & & & & & & & \\
\hline 7 & Social Issues & & & & & & & & \\
\hline 8 & $\begin{array}{l}\text { Employee Education } \\
\text { and Trade Skills }\end{array}$ & & & & & & & & \\
\hline
\end{tabular}

Figure 12: Adjacency matrix, populated.

as the one identified in the previous ISM evaluation. Note that the design matrix used for the evaluation of the unemployment factors does not have multiple domain mappings, and only deals with the unitary domain Found in the Kano Survey's factors (Figure $12)$. 


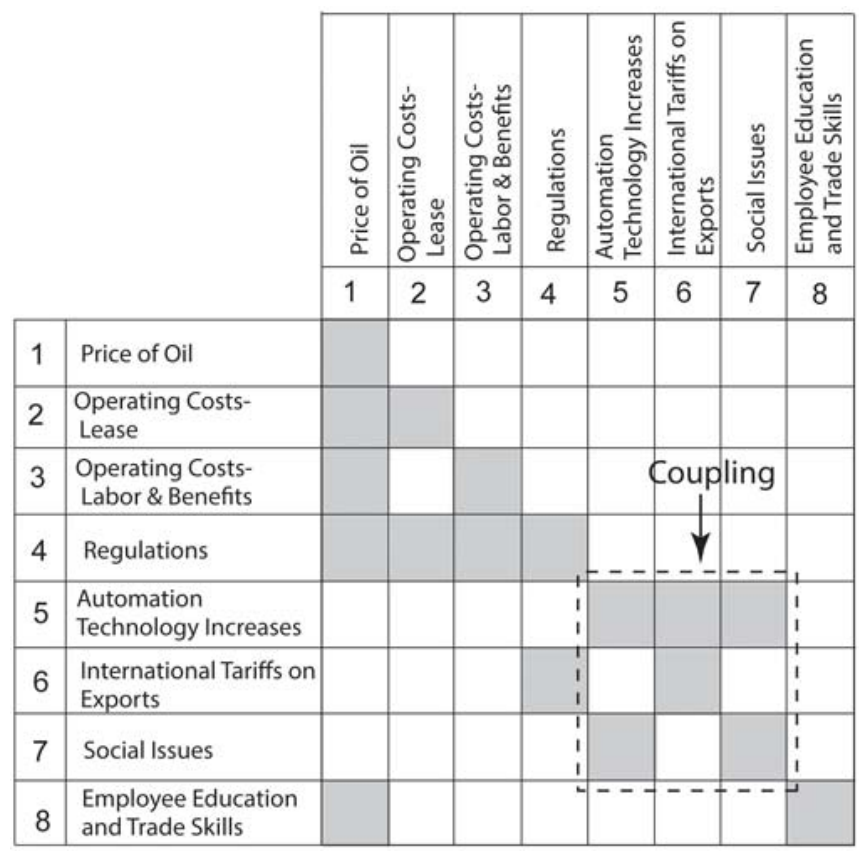

Figure 13: Adjacency matrix, adjusted.

Column six is empty, so column and row six get moved to the periphery (Figure 13). The adjusted adjacency matrix, indicates coupling between Automation Technology Increases and Employee Education and Trade Skills, (Figure 13), so these are collapsed into one factor for further evaluation (Figure 14). The collapsed chart indicates that the newly coupled multi factor column is empty, so it gets moved to the outside, which also moves the coupled row to the bottom (Figure 15). This action also completes the available interation with the adjacency matrix, so we uncouple the two factors coupled for evaluation, and identify our series and coupled factors (Figure $16)$.

From Figure 16, we can see with the two series, 'Lease Operating Costs' directly impacts 'Price of Oil', and that 'Regulations' directly impacts 'Operating Costs Associated with Labor and benefits', with additional coupling found between 'Employee education and trade skills' and 'Automation Technology Increases'.

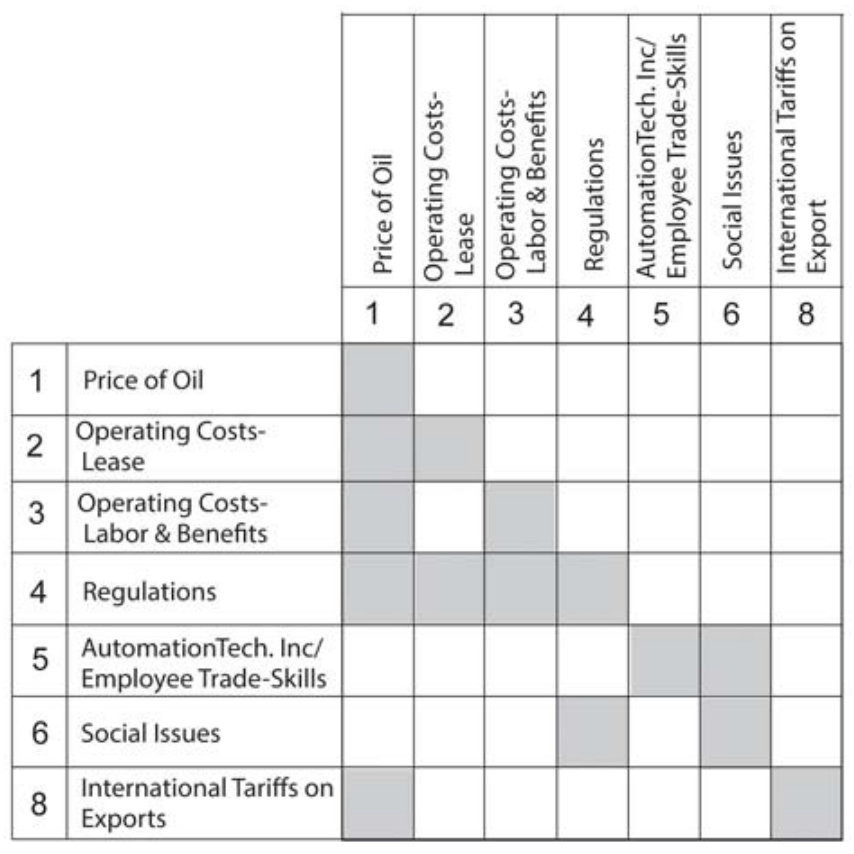

Figure 14: Adjacency matrix, collapsed.

\begin{tabular}{|c|c|c|c|c|c|c|c|c|}
\hline & 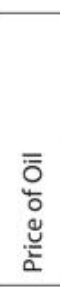 & 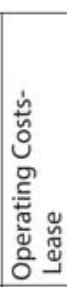 & 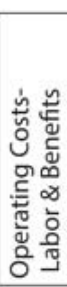 & 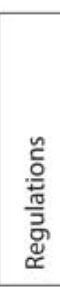 & 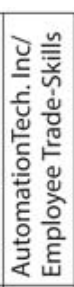 & 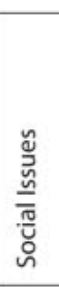 & 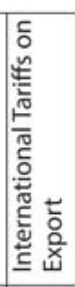 \\
\hline & & 1 & 2 & 3 & 4 & 5 & 6 & 8 \\
\hline 1 & Price of Oil & & & & & & & \\
\hline 2 & $\begin{array}{l}\text { Operating Costs- } \\
\text { Lease }\end{array}$ & & & & & & & \\
\hline 3 & $\begin{array}{l}\text { Operating Costs- } \\
\text { Labor \& Benefits }\end{array}$ & & & & & & & \\
\hline 4 & Regulations & & & & & & & \\
\hline 5 & $\begin{array}{l}\text { AutomationTech. Inc/ } \\
\text { Employee Trade-Skills }\end{array}$ & & & & & & & \\
\hline 6 & Social Issues & & & & & & & \\
\hline 8 & $\begin{array}{l}\text { International Tariffs on } \\
\text { Exports }\end{array}$ & & & & & & & \\
\hline
\end{tabular}

Figure 15: Adjacency matrix, collapsed, updated.

\subsection{DSM - Results}

The final interesting factor was the looped dependency between automation technology increases and employee education and skilled labor availability. Automation influences employee skill levels by seemingly perpetually requiring new and evolving skillsets. Employees, in turn, in order to maintain proficiency levels as well as reamain viable as candidates in 


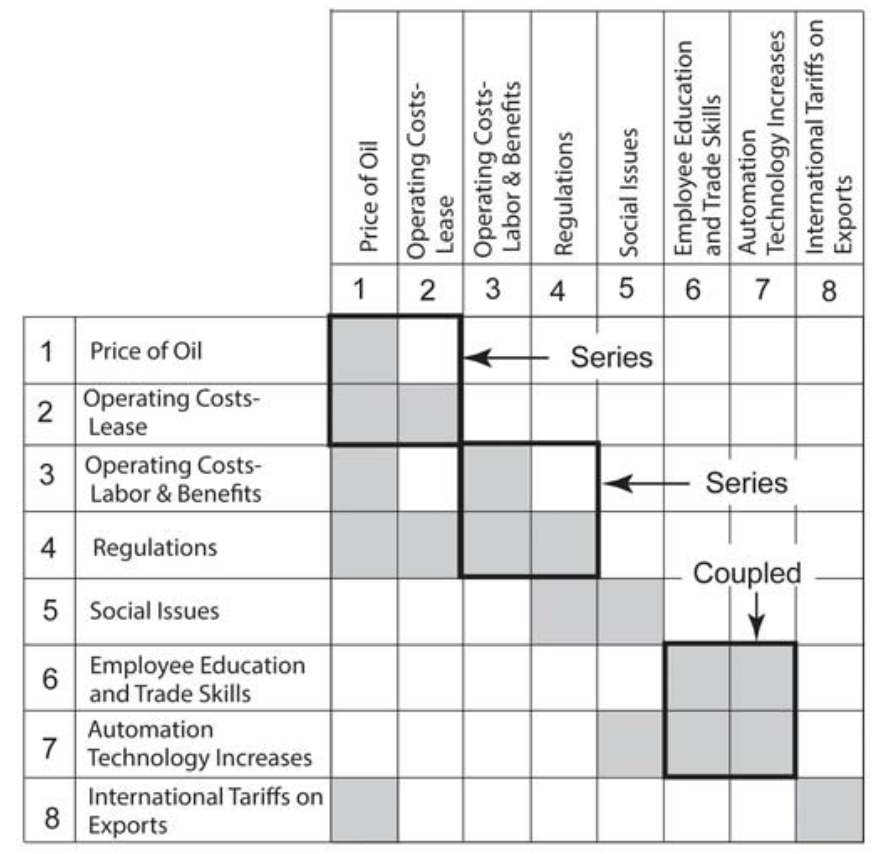

Figure 16: Adjacency matrix, final.

an increasingly constricted labor to skill-set worker pool, must strive to keep updated their skillsets, in order to adapt to advances in fields like automation. Employee skill levels impact automation directly through the growing gap between unskilled and skilled labor. The growing educational requirements for technological based jobs, in fields like manufacturing, are being outpaced by the lack of adequately skilled labor (specifically defined as labor between unskilled and skilled) [12]. This gap, seen as a lack of viable labor for positions of moderate skill, drive requirements for automation, thus circuitiously driving an increase for highly skilled labor. In summation, while these two factors (automation and education) obviously greatly influence each other, their combined impact on factors like regulations had a large ripple throughout the rest of the significant factors identified as having a large impact on unemployment in the United States Petroleum Industry.

\section{Conclusion}

Having worked within the Transdisciplinary Research Process and through the application of ISM and DSM techniques, we conclude that investments in research and development of new technologies combined with efforts to increase the education level and skilled labor pool of employees within the United
States will positively impact unemployment rates within the Petroleum Industry, as these factors drive the Price of Oil through an enumeration of factors discussed in the paper above. The Price of Oil directly goes to the bottom line profitability of Petroleum companies and therefore leads to employment/unemployment within the Petroleum Industry. It is this grass roots solution approach (e.g., education/skilled labor combined with the development of new technologies) that can directly address current and future unemployment issues in the Petroleum industry.

Future and more comprehensive research into these factors is required in order to provide additional levels of detail in the solution space. In particular, answering the question as to how secondary and post-secondary schools could isolate and expand applicable areas of education for future energy sector jobs as well as provide increased training in skilled labor, such as welding, would be valuable for the industry to understand. Additional research projects could lead to new educational tracks or standards as well as vocational school focus areas to help the Petroleum industry in its quest to draw down unemployment over the long run as well as provide stability its sector of the overall U.S. job market.

Overall, it is certain that investing in these areas: education and research \& development of new technologies will lead to positive impacts for unemployment rates in the U.S. petroleum industry.

\section{Acknowledgements}

The research team would like to acknowledge the efforts expended by Utku Gulbulak, in introducing and illustrating the Transdisciplinary Research Process to our team. Furthermore, our TD Team would like to acknowledge Mr. Robert Davis for his participation as a Subject Matter Expert during the early parts of the research. And finally, we would like to thank all of the participants of the Kano Survey that provided valuable input and insight that helped to shape the areas of our research: Ms. Britttney Davis, Mr. Brian Davis, Mr. Robert Davis, Mr. Ray West, Mr. Dewayne Kelley, Mr. Robert Evers, Mr. Beau Galloway, Mr. Tyson McMahon, and Mr. John Thomas among others.

Author Contributions: Paper was written collaboratively by the authors. 
Funding: This research received no external funding.

Conflicts of Interest: The authors declare no conflict of interest.

\section{References}

[1] American Petroleum Institute (2013). Economic Impacts of the Oil and Natural Gas Industry on the US Economy in 2011. [Online]. Available: http://www.api.org/news-policy-andissues/american-jobs/economic-impacts-of-oil-andnatural-gas.

[2] Brown, S. P. a. M. K. Y. (2013). The Shale Gas and Tight Oil Boom: U.S. States' Economic Gains and Vulnerabilities. [Online]. Available: http://www.cfr.org/united-states/shalegas-tight-oil-boom-us-states-economic-gainsvulnerabilities/p31568.

[3] Bureau of Labor Statistics, (2017). Oil and Gas Extraction: NAICS 2011. [Online]. Available: https://www.bls.gov/iag/tgs/iag211.htm.

[4] Riffkin, R. (2014). Unemployment Rises to Top Problem in the U.S. [Online]. Available: http://www.gallup.com/poll/167450/unemploymentrises-top-problem.aspx.

[5] Belle, D. a. H. E. B. The Psychological Consequences of Unemployment. [Online]. Available: https://www.spssi.org/index.cfm? fuseaction $=$ page. viewpage\&pageid $=1457$.

[6] Margarita, R. C. a. J. R. L. A. (2016). Multidisciplinary Approach For Curriculum Design of Professional Master's Program with Focusing On Solidary Economy In Oaxaca, Mex. Educational Research And Reviews, 11(14), 1317-1323.

[7] Stinner, D. J. (2016). Improving Outcomes Following Extremity Trauma: The Need For A Multidisciplinary Approach. Military Medicine, 181, 26-29.

[8] Viorica, B., Codruta, G., Mihaela, L. M. (2016). Interdisciplinarity - A Requisite Of Modern Education. Research Journal Of Agricultural Science, 48(4), 190-193.

[9] Ertas, A., J. R. P. C. T. B. A. (2015). Transdisciplinary Collaboration as a Vehicle for Collective Intelligence: A Case Study of Engineering Design Education. International Journal of Engineering Education. 31(6), 1526-1536.

[10] Ertas, A. (2016). Transdisciplinary Design Process \& Systems Complexity. in Texas Tech Univeristy Course Instruction, Lubbock, Texas.
[11] U.S Energy Informatin Administration, (2016). Trends in U.S. Oil and Natural Gas Upstream Costs. U.S Energy Informatin Administration, Washington, D.C.

[12] Morrison,T., DeRocco, E. S., Maciejewski, B., McNelly, J., Giffi C., and Carrick, G. (2011). Boiling point? The skills gap in U.S. manufacturing; A report on talent in the Manufacturing industry., in The Manufacturing Institute, Deloitte \& The Manufacturing Institute, p. 16.

[13] U. S. E. P. Agency, (2015). Regulatory Impact Analysis of the Proposed Emissions Standards for New and Modified Sources in the Oil and Natural Gas Sector. August 2015. [Online]. Available: https://www.epa.gov/climatechange/regulatoryimpact-analysis-proposed-emission-standards-newand-modified-sources-oil.

[14] Snyder, J. (2015). How the 'rise of the machines' will transform oil and gas. Alberta Oil, 16 March 2015.

[15] N. Nerurkar, N. (2012). U.S. Oil Imports and Exports. Congressional Research Service, Washington, D.C., 2012.

[16] Eyermann, C. (2014). The Expanding Regulation of the American People. MyGovCost.Org, 8 September 2014. [Online]. Available: http://www.mygovcost.org/2014/09/08/theexpanding-regulation-of-the-american-people/. [Accessed 31 January 2017].

[17] Slutz, J. (2017). Energy Policy-Building on Abundance. U.S. Chamber of Commerce Foundation, [Online]. Available: https://www.uschamberfoundation.org/energypolicy-building-abundance. [Accessed 02 February 2017].

[18] Stevens, B. (2013). A Look at Unconventional Oil and Gas Regulations. OilPrice.com, 03 September 2013. [Online]. Available: http://oilprice.com/Energy/EnergyGeneral/A-Look-at-Unconventional-Oil-and-GasRegulations.html. [Accessed 31 January 2017].

[19] Wikipedia, (2017). Structural Unemployment. January 2017. [Online]. Available: https://en.wikipedia.org/wiki/Structural_unemploy ment.

[20] Organization for Economic Co-operation and Development, "Unemployment Rates by Education Level," 2016. [Online]. Available: https://data.oecd.org/unemp/unemploymentrates-by-education-level.htm\#indicator-chart. 
[21] Balch, O. (2015). What will happen to oil and gas workers as the world turns carbon neutral? The Guardian, 27 August 2015.

[22] Blum, J. (2016). Fewer jobs in oil patch as automation picks up. Houston Chronicle, 21 December 2016.

[23] Cunningham, N. (2016). Oil Companies Face Worker Shortages After 350,000 Layoffs. USA Today, 12 June 2016.

[24] Nizri, G. (2017). How Automation Technology is Solving the Cybersecurity Staffing Shortage Issue. Ayehu, 31 January 2017.

[25] Security, I. (2016). Hacking the Skills Shortage. [Online]. Available: https://www.mcafee.com/us/resources/reports/rphacking-skills-shortage.pdf.

[26] Wikipedia, January 2017. [Online]. Available: https://en.wikipedia.org/wiki/Social_issue.

[27] F. Aliyeva, F. (2012). Top 10 Challenges in Oil and Gas Industry. Intelligent HQ, 2 September 2012.

[28] Nyquist, S. (2015). Lower oil prices but more renewables: What's going on? June 2015. [Online]. Available: http://www.mckinsey.com/industries/oiland-gas/our-insights/lower-oil-prices-but-morerenewables-whats-going-on.

[29] U.S. Energy Information Administration, (2016). "What is the U.S. electricity generation by energy source?," April 2016. [Online]. Available: https://www.eia.gov/tools/faqs/faq.cfm?id=427\&t $=3$.

[30] J. Herrera, J. (2016). Monterey Poised to Become State's First Oil-Producing County to Ban Fracking. The Mercury News, 10 November 2016.

[31] Cook,T. a. J. P. (2016). Hydraulic Fracturing Accounts for About Half of Current U.S. Crude Oil Production. 15 March 2016. [Online]. Available: http://www.eia.gov/todayinenergy/detail.php?id= 25372 .

[32] Farris, A. (2012). How big data is changing the oil \& gas industry. Analytics Magazine, November 2012.

[33] Warfield, J.N. (1974). Developing Subsystem Matrices in Structural Modeling. IEEE Transactions on Systems, Man, and Cybernetics, 4(1), 74-80.

[34] Wikipedia, (2017). January 2017. [Online]. Available: https://en.wikipedia.org/wiki/Reachability.
[35] Malone, D. W. (1975). An Introduction to the Application of interpretive Structural Modeling. Proceedings of the IEEE, 63(3), 397-404.

[36] Ertas, A. (2016). Transdisciplinary Trans-Sector Integration in Education: Convergence. Transdisciplinary Journal of Engineering 85 Science. 6, no. 1949-0569, pp. 103-116.

[37] A. Ertas, A. (2010). Understanding of Transdiscipline and Transdisciplinary Process. Transdisciplinary Journal of Engineering \& Science. vol. 1, no. 1949-0569, pp. 55-73.

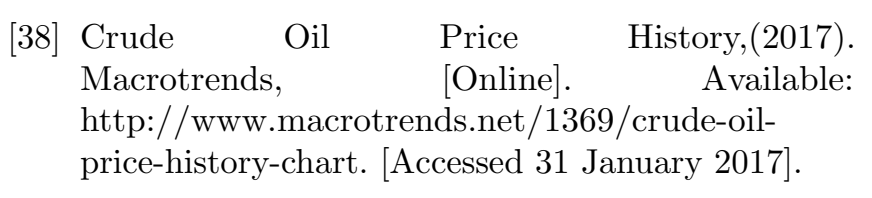

\section{About the Authors}

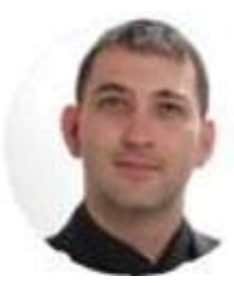

Daniel Moran is a Senior Engineering Manager with the Raytheon Company, where he has served in many positions in Software, Hardware and Systems Engineering departments since beginning employment in 1999. A graduate of Texas Tech University and Lamar University, Daniel holds M.S. degrees in Mathematics and Systems Engineering and a B.S. in Mathematics. Daniel is currently engaged in research through the Texas Tech University Mechanical Engineering Department and Rawls College of Business as he pursues his Ph.D. in Transdisciplinary Studies with a focus on Organizational and Transactional Cost Economics. Daniel has previously been part of an international marketing start-up company and was a Principal in a separate oil and gas services start-up company, based out of Houston. Daniel is married with three children and calls Heath, TX his home.

C.E.B Kreger obtained his Bachelors of Science from Sul Ross State University, in Alpine, Texas, and is currently working on his Masters of Engineering from Texas Tech University, in Lubbock, Texas. For his Masters Thesis, he is working on exploring the impacts of automation in infrastructure deployments, and possibilities within that field for driving down cost and increasing reliability. Chris has over fifteen years of experience in the industry of computer and information technology, and has a passion for computer hardware and the advances in technology. An avid gamer and automotive enthusiast, Chris 
spends his time playing board games with his family, and working on his automobiles.

Stacie Therson obtained her Bachelors of Science degrees in Electrical Engineering and Mathematics at Southern Methodist University, in Dallas, TX. Stacies career has been devoted to systems engineering, with the majority being in the defense industry. While working, she received her Masters in Systems Engineering, from the Mechanical Engineering department at Texas Tech University, in Lubbock, Texas, where she is currently pursuing a doctorate in Transdisciplinary Engineering. Her dissertation is quantifying the environmental factors impact on the reliability of non-electronic parts. 


\section{APPENDIX-A}

\section{Appendix of Abbreviations}

AGOA - African Growth and Opportunities Act

BLM - Bureau of Land Management

CIA - Cross-Impact Analysis

DSM - Design Structure Matrix

EFC - Eagle Ford Capex

EIA - Energy Industry Administration

EPA - Environmental Protection Agency

FEED - Front End Engineering Design

FERC - Federal Energy Regulatory Commission

GDP - Gross Domestic Product

GSP - Generalized System of Trade Preferences

ISM - Interpretive Structural Modeling

LOE - Lease Operating Expenses

MICMAC - Impact Matrix Cross-Reference Multiplication Applied to a Classification

NAFTA - North American Free Trade Agreement

NGT - Nominal Group Technique

OPEC - Organization of the Petroleum Exporting Countries

OSHA - Occupational Safety and Health Administration

R\&D - Research and Development

SPS - Societal Problem Solving

SSIM - Structural Self-Interaction Matrix

TD - Transdisciplinary

UAM - Updated Adjacency Matrix

U.S. United States

\section{Kano Survey}

The Kano style survey below was used as part of the Transdisciplinary process in identifying the factors that were to be considered in the research. A large set of factors was initially conceived through brainstorming among the transdisciplinary team; however, the final selection of factors was driven by subject matter expert (SME) input from those who work and are decision makers in the Petroleum Industry. See Figure A-1 below. 


\begin{tabular}{|c|c|c|}
\hline Question * & Survey Question & Answer \\
\hline 1 & $\begin{array}{l}\text { In order to understand what factors impact unemployment rates for the Oil \& Gas inchustry in West Texas, the factor "Cost of } \\
\text { labor and Benefils (Taves, Insurance, Pension, efc)" must be included in the research and assersment. }\end{array}$ & \\
\hline 2 & $\begin{array}{l}\text { When attempting to understand the factors that impact unemployment rates for the Oil \& Gas industry in West Texas, I do not } \\
\text { need to consider the factor "Cost of Labor and Benefils (Taces, lnsurance, Pension, etc)" in the research. }\end{array}$ & \\
\hline 3 & 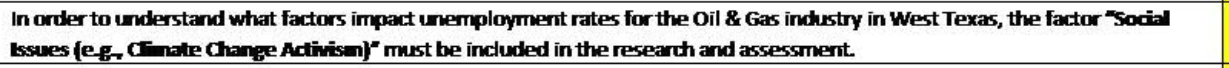 & \\
\hline 4 & 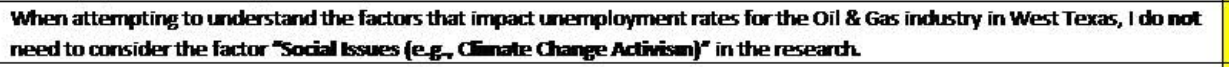 & \\
\hline 5 & 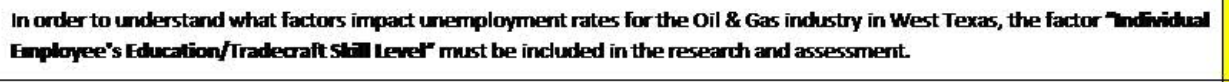 & \\
\hline 6 & 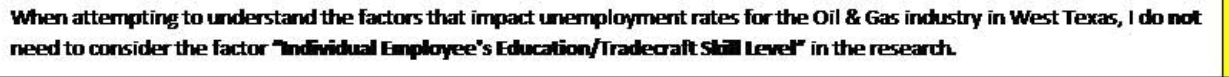 & \\
\hline 7 & $\begin{array}{l}\text { In order to understand what factors impact unemployment rates for the Oil \& Gas industry in West Texas, the factor Tegional } \\
\text { lob Warlet Competition in the Energy Sector (Wind, Solar, Coal, efc)" " must be included in the research and assessment. }\end{array}$ & \\
\hline 8 & $\begin{array}{l}\text { When attempting to understand the factors that impact unemployment rates for the Oil \& Gas inchstry in West Texas, I do not } \\
\text { need to consider the factor Thegional lob Marhet Competition in the Energy Sector (Wind, Solar, Coal, etc) " in the research. }\end{array}$ & \\
\hline 9 & $\begin{array}{l}\text { In order to understand what factors impact unemployment rates for the Oil \& Gas industry in West Texas, the factor "US } \\
\text { Regulations (EPA, OsiA, FEC, etc)" must be included in the research and assessment. }\end{array}$ & \\
\hline 10 & $\begin{array}{l}\text { When attempting to understand the factors that impact umemployment rates for the Oil \& Gas industry in West Texas, I do not } \\
\text { need to consider the factor "US Regulations (BPA, OSHA, FEC, etc)" in the research. }\end{array}$ & \\
\hline 11 & $\begin{array}{l}\text { In order to understand what factors impact umemployment rates for the Oil \& Gas industry in West Texas, the factor 7ease } \\
\text { Operating Expenses" must be included in the research and assessment. }\end{array}$ & \\
\hline 12 & $\begin{array}{l}\text { When attempting to understand the factors that impact unemployment rates for the Oil \& Gas industry in West Texas, I do not } \\
\text { need to consider the factor 7ease Operaling Expenses" in the research. }\end{array}$ & \\
\hline 13 & $\begin{array}{l}\text { In order to understand what factors impact unemployment rates for the Oil \& Gas inchustry in West Texas, the factor "Price of } \\
\text { OF must be included in the research and assessment. }\end{array}$ & \\
\hline 14 & $\begin{array}{l}\text { When attempting to understand the factors that impact unemployment rates for the Oil \& Gas industry in West Texas, I do not } \\
\text { need to consider the factor Price of } 0 \text { " in the research. }\end{array}$ & \\
\hline 15 & 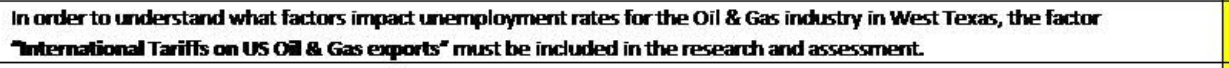 & \\
\hline 16 & $\begin{array}{l}\text { When attempting to understand the factors that impact unemployment rates for the Oil \& Gas industry in West Texas, I do not } \\
\text { need to consider the factor Tinternational Tariffs on us on \& Gas exports" in the research }\end{array}$ & \\
\hline 17 & $\begin{array}{l}\text { In order to understand what factors impact unemployment rates for the Oil \& Gas industry in West Texas, the factor 7ncrease in } \\
\text { the use of Automation Technology" must be included in the research and assessment. }\end{array}$ & \\
\hline 18 & $\begin{array}{l}\text { When attempting to understand the factors that impact unemployment rates for the Oil \& Gas industry in West Texas, I do not } \\
\text { need to consider the factor 7ncrease in the use of Automation Technologry in the research. }\end{array}$ & \\
\hline 19 & $\begin{array}{l}\text { In order to understand what factors impact unemployment rates for the Oil \& Gas industry in West Texas, the factor "OPEC } \\
\text { production and output amounts" must be included in the research and assessment. }\end{array}$ & \\
\hline 20 & $\begin{array}{l}\text { When attempting to understand the factors that impact unemployment rates for the Oil \& Gas inchustry in West Texas, I do not } \\
\text { need to consider the factor "OpEC production and output amounts" in the research. }\end{array}$ & \\
\hline 21 & 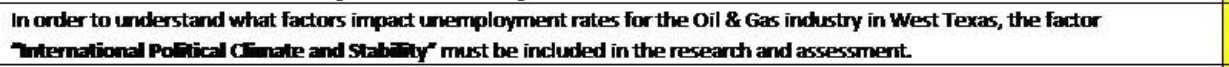 & \\
\hline 22 & 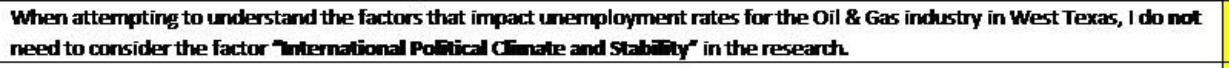 & \\
\hline 23 & 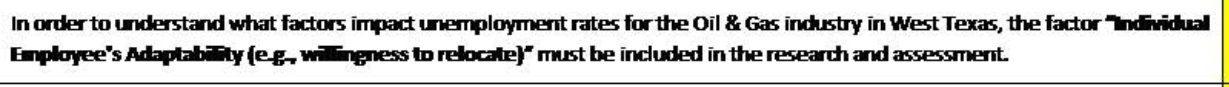 & \\
\hline 24 & 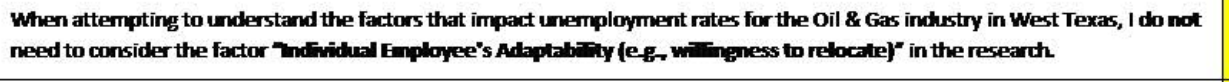 & \\
\hline $\mathbf{5}$ & $\begin{array}{l}\text { In order to understand what factors impact unemployment rates for the Oil \& Gas industry in West Texas, the factor "US } \\
\text { Lnport/Export Tariffs" must be included in the research and assessment. }\end{array}$ & \\
\hline 26 & $\begin{array}{l}\text { When attempting to understand the factors that impact unemployment rates for the Oil \& Gas industry in West Texas, I do not } \\
\text { need to consider the factor Yo Lnport/Export Tariffs" in the researth. }\end{array}$ & \\
\hline
\end{tabular}

Figure A-1:

Kano Survey \& Questionnaire utilized in determine the factors to be considered in the research. 


\begin{tabular}{|c|c|c|c|c|c|c|c|c|}
\hline Factor & $\mathrm{M}$ & 0 & A & 1 & $\mathbf{R}$ & Q & Category & Possble Categorles \\
\hline $\begin{array}{l}\begin{array}{l}\text { Cost of Labor and Benefits (Taxes, Insurance, Pension, } \\
\text { etc) }\end{array} \\
\end{array}$ & 9 & 1 & 1 & & & & M & $M=$ Must Be \\
\hline Sodal Issues (e.g., Climate Change Activism) & 2 & 1 & 1 & 2 & 5 & & $R$ & $0=$ Optional \\
\hline Individual Employee's Eduction/Tradecraft Skill Level & 7 & 2 & & 1 & 1 & & M & $A=$ Attriactive \\
\hline $\begin{array}{l}\text { Regional Job Market Competition in the Energy Sector } \\
\text { (Mnd, Solar, Coal, etc) }\end{array}$ & 3 & 2 & & 5 & 1 & & 1 & I = Indlifferent ( No Preference) \\
\hline US Regulations (EPA, OSHA, FERC, etC) & 6 & 1 & 2 & 1 & 1 & & M & $R=$ Reverse (Can be elther way) \\
\hline Lease Operating Expenses & 6 & 1 & 1 & 2 & 1 & & M & $Q=$ Questlonable (Wrong Answer) \\
\hline Price of oll & 9 & 1 & & 1 & & & M & \\
\hline International Tanffs on LS OII \& Gas exports & 4 & 1 & 1 & 4 & 1 & & $\mathrm{M}$ & \\
\hline Increase in the use of Automation Technology & 2 & 4. & 1 & 3 & 1 & & 0 & \\
\hline OPEC production and output amounts & 4 & 1 & 2 & 3 & 1 & & $M$ & \\
\hline Intemational Political Climate and Stability & 2 & 1 & 1 & 5 & 2 & & 1 & \\
\hline $\begin{array}{l}\text { Individual Employee's Adaptablity (e.g, willingness to } \\
\text { relocate) }\end{array}$ & 4 & 2 & & 2 & 3 & & $R$ & \\
\hline US Import/Export Tariffs & 3 & 1 & 1 & 5 & 1 & & 1 & \\
\hline
\end{tabular}

Figure A-2:

Kano survey results.

\begin{tabular}{|c|c|c|c|c|c|c|}
\hline \multirow[b]{2}{*}{ Customer Requirement } & & \multicolumn{5}{|c|}{ Negative Question (Dysfunctional) } \\
\hline & & $\begin{array}{l}1-1 \text { uke It } \\
\text { That Way }\end{array}$ & $\begin{array}{c}2-1 \mathrm{t} \\
\text { Must be } \\
\text { That Way }\end{array}$ & $\begin{array}{c}3- \\
\text { Neutral }\end{array}$ & \begin{tabular}{|c|}
$4-I$ can \\
Live with \\
It that \\
Way \\
\end{tabular} & $\begin{array}{c}5-1 \\
\text { dislike It } \\
\text { that way }\end{array}$ \\
\hline \multirow[b]{5}{*}{ Positive Question (Functional) } & $\begin{array}{l}\text { 1-I Uke It That } \\
\text { Way }\end{array}$ & $\mathbf{Q}$ & A & A & A & o \\
\hline & $\begin{array}{c}\text { 2-It Must be } \\
\text { That Way }\end{array}$ & $\mathbf{R}$ & 1 & 1 & 1 & M \\
\hline & 3-Neutral & $\mathbf{R}$ & 1 & 1 & 1 & M \\
\hline & $\begin{array}{c}4-1 \text { can Uive } \\
\text { with it that Way }\end{array}$ & $\mathbf{R}$ & 1 & 1 & 1 & M \\
\hline & $\begin{array}{c}5 \text { - Idislike It } \\
\text { that way }\end{array}$ & $\mathbf{R}$ & $\mathbf{R}$ & $\mathbf{R}$ & $\mathbf{R}$ & $\mathbf{Q}$ \\
\hline
\end{tabular}

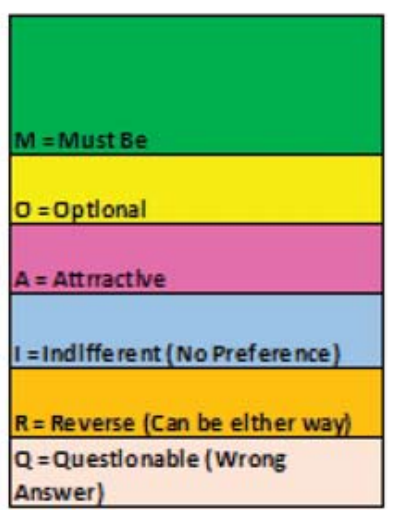

Figure A-3:

Kano analysis mapping. 